\title{
Neurotensin-like immunoreactivity after intestinal resection in the rat
}

\author{
P S OLSEN, J H PEDERSEN, S S POULSEN, Y YAMASHITA, \\ AND P KIRKEGAARD \\ From the Department of Surgery C, Rigshospitalet and Department of Anatomy B, University of Copenhagen, \\ Copenhagen, Denmark
}

SUMmARY Neurotensin is a tridecapeptide located mainly in the distal small intestine. The present study was carried out in order to investigate the neurotensin response after proximal small intestinal resection in the rat. After resection, the median plasma concentration of neurotensin like immunoreactivity (NTLI) was unchanged compared with sham operated rats. Intragastric instillation of fat increased the plasma concentration of NTLI from $45 \mathrm{pmol} / \mathrm{l}$ (34-63) in sham operated rats to $92 \mathrm{pmol} / \mathrm{l}(46-121)$ in resected rats. No significant increase in the plasma concentration of NTLI was found after intragastric instillation of amino acids or glucose. The tissue concentration of NTLI increased significantly in the jejunum and ileum after proximal small intestinal resection, while the number of immunoreactive neurotensin cells was unchanged. This study shows that the adaptive responses in the distal small intestine after proximal small intestinal resection also involve the neurotensin producing cells.

Neurotensin is a tricedapeptide localised in the brain, peripheral nerves, and endocrine cells of the intestinal mucosa. ${ }^{1-3}$ Neurotensin immunoreactive cells occur throughout the gastrointestinal tract with increasing density towards the ileum. ${ }^{+}$Increased concentration of circulating neurotensin occurs after ingestion of fat, whereas glucose or amino acids produce a minor or no secretory response in man and rat. ${ }^{56}$

Resection of the proximal small intestine in rats induces adaptive changes in the remaining small intestine. These include an increased crypt cell production rate with increased rate of cell migration to the villi and consequently enlargement of the villi. ${ }^{7}$ Macroscopically, the residual small intestine is dilated, thickened, and elongated. ${ }^{8}$ Functionally, there is increased absorption per unit of length and a reduction in intestinal transit time. ${ }^{910}$ Food intake, pancreatic juice and bile seem to be important factors in initiating the adaptive response, these effects may

Address for correspondence: Peter Skov Olsen, Dept of Surgery C. 2122. Rigshospitalet, Blegdamsvej 9, 2100, Copenhagen, Denmark.

Received for publication 5 February 1987. be mediated by regulatory peptides. ${ }^{11-13}$ In the distal small intestine enteroglucagon cells and neurotensin containing cells are present. ${ }^{1+}$ The plasma concentration of enteroglucagon is persistently raised after proximal small intestinal resection, and it has been suggested that enteroglucagon may be involved in initiation of the postresectional ileal hyperplasia. ${ }^{15}$ The present study was undertaken to investigate the NTLI response after proximal small intestinal resection in the rat. In addition the concentration of NTLI in the distal jejunum and ileum were compared before and after resection.

\section{Methods}

EXPERIMENTAL PROCEDURE

Twenty male Wistar rats weighing approximately $300 \mathrm{~g}$ were studied. Before each experiment the rats were fasted overnight but allowed free access to water. The rats were divided into two groups of 10 rats. In the first group approximately $60 \%$ of the proximal small intestine was resected as measured from the ligament of Treitz, leaving the distal jejunum and ileum intact. The other group under- 
went transsection and reanastomosis at the ligament of Treitz and served as controls. Intestinal continuity was restored with an end to end anastomosis. Four weeks later all rats had a polyethylene catheter placed in a jugular vein. At intervals of one week, $2 \mathrm{ml}$ blood was drawn from the jugular vein 20 minutes after intragastric instillation of $2 \mathrm{ml}$ of one of the following agents: Intralipid (Kabi Vitrum, Sweden), Aminess (Kabi Vitrum), glucose $20 \%$ and saline $0 \cdot 154 \mathrm{~mol} / \mathrm{l}$. Plasma was stored at $-20^{\circ} \mathrm{C}$ for later determination of NTLI. Ten days after the last investigation all rats were killed and specimens from the distal jejunum and distal ileum were removed for quantification and immunohistochemical localisation of neurotensin.

\section{LABORATORY ANALYSES}

The concentration of NTLI was determined by radioimmunoassay in unextracted plasma as previously described. ${ }^{16}$ The antiserum used (code no $759 \mathrm{~A}-4$ ) requires the entire sequence of neurotensin for the antigen-antibody reaction and does not react with smaller fragments of neurotensin. ${ }^{\text {th }}$ The antiserum does not crossreact with other known gastrointestinal peptides. Antiserum was raised in rabbits by immunisation with neurotensin 1-13. Monoiodated neurotensin ( ${ }^{125} \mathrm{I}$ ( Tyr-3)-NT) was used as tracer and neurotensin 1-13 (Beckman, Ca-USA) as standard. ${ }^{17}$ Detection limit of the assay is $3 \mathrm{pmol} / \mathrm{l}$ and the working range $3-100 \mathrm{pmol} / \mathrm{l}$. Intra-assay and interassay variation is below $15 \%$.

For quantification of neurotensin all tissue samples were weighed at $-20^{\circ} \mathrm{C}$, homogenised in 10 -fold weight of cold $2.0 \mathrm{~mol} / \mathrm{l}$ acetic acid for five minutes. Homogenates were bathed in boiling water for 10 minutes. Insoluble material was removed by centrifugation at $3000 \mathrm{rpm}$ for 20 minutes at $4^{\circ} \mathrm{C}$, and the supernatant lyophilised. Radioimmunoassay of lyophilised extracts, reconstituted in $0.02 \mathrm{~mol} / \mathrm{l}$ phosphate buffer $\mathrm{pH} 7.4$ with $0.2 \%$ albumin and $0.01 \%$ thiomersal (assaybuffer), were carried out at five dilutions to span the sensitive part of the dose response curves. The reading from the middle of the curve was used and results expressed as pmol/g tissue. Recovery of synthetic neurotensin added to tissue before extraction was $97 \cdot 6 \pm 3 \cdot 9 \%$ (mean $\pm S D$, $\mathrm{n}=10)$. Tissue extracts from all rat studies were assayed in random order within one assay.

Gel filtration was done at room temperature using Sephadex G-25 superfine column $(1.6 \times 100 \mathrm{~cm})$ (Pharmacia Fine Chemicals, Sweden). Crude extracts of pooled ileal and jejunal specimens $(30 \mathrm{~g})$ were reconstituted with $1 \mathrm{ml}$ of $0 \cdot 1 \mathrm{~mol} / \mathrm{l}$ acetic acid. The column was eluted with $0 \cdot 1 \mathrm{M}$ acetic acid with a flow of $10 \mathrm{ml} / \mathrm{h}$. The eluate of fractions of $1.1 \mathrm{ml}$ were collected, lyophilised and reconstituted in assay buffer. Column was calibrated with human serum albumin, "'Na ${ }^{+}$, and NT 1-13. Trace amounts of albumin and ' $\mathrm{Na}$ ' were added to all samples for internal calibration. Recovery was above $84 \%$.

Specimens for immunohistochemical localisation of neurotensin were fixed by perfusion in Bouin's fixative without acetic acid. The immunohistochemical technique used was the unlabelled peroxidase-antiperoxidase method (PAP). The antiserum 3844 was diluted $1: 1600$. In control sections the antibody was preincubated with synthetic neurotensin 1-13 $10 \mu \mathrm{mol} / \mathrm{l}$. Quantification of the number of immunoreactive cells was carried out on perpendicularly oriented sections consisting of the entire thickness of the mucosa. The number of immunoreactive cells per 10 crypt-villi and per unit length of muscularis mucosae were counted. In the latter a graticule oriented parallel to the muscularis mucosae was used and all immunoreactive cells were counted.

\section{STATISTICAL ANALYSIS}

Statistical evaluation of the results was performed by Wilcoxon's test for paired differences and the MannWhitney test for unpaired samples. Results are given as medians and total ranges.

\section{Results}

In sham operated rats the median plasma concentration of NTLI was $18 \mathrm{pmol} / \mathrm{l}$ (range 13-34) after intragastric instillation of saline. Instillation of Intralipid significantly increased the median plasma concentration of NTLI to $45 \mathrm{pmol} / \mathrm{l}$ (range 34-63), whereas instillation of glucose $20 \%$ or Aminess had no significant effect (Table 1). After proximal small intestinal resection the concentration of NTLI was 26 $\mathrm{pmol} / \mathrm{l}$ ( range 20-38). Intralipid increased the concentration of NTLI to $92 \mathrm{pmol} / \mathrm{l}$ (range 46-121) while instillation of glucose $20 \%$ or Aminess had no significant effect. In resected rats the plasma concentration of NTLI after instillation of Intralipid was significantly higher than in sham operated rats. The

Table 1 Effect of proximal small intestinal resection on concentration of NTLI in plasma after intragastric administration of saline, glucose, amino acids or fat

\begin{tabular}{lll}
\hline Treatment & $\begin{array}{l}\text { Shamoperation }(n=10) \\
\text { pmol/l }\end{array}$ & $\begin{array}{l}\text { Resection }(n=I 0) \\
\text { pnol/l }\end{array}$ \\
\hline Saline & $18(13-34)$ & $26(20-38)$ \\
Glucose $20 \%$ & $25(22-37)$ & $35(17-58)$ \\
Aminess & $19(13-32)$ & $23(15-38)$ \\
Intralipid & $45^{*}(34-63)$ & $92+(46-121)$ \\
\hline
\end{tabular}

Values are given as medians and total ranges. ${ }^{*} p<() \cdot() 1$ compared with sham operated rats given saline. $\nmid p<0.01$ compared with resected rats given saline and sham operated rats given Intralipid. 
Table 2 Concentration of NTLI in the distal jejunum and ileum in sham operated rats and in rats subjected to proximal small intestinal resection

\begin{tabular}{lll}
\hline Organ & $\begin{array}{l}\text { Shamoperation }(n=8) \\
\text { pmol/g }\end{array}$ & $\begin{array}{l}\text { Resection }(n=8) \\
p m o l / g\end{array}$ \\
\hline Jejunum & $1 \cdot 76(0 \cdot 88-38 \cdot 9)$ & $26 \cdot 7^{*}+(9 \cdot 1-67 \cdot 3)$ \\
Ileum & $1 \cdot 47(0 \cdot 18-3 \cdot 27)$ & $4 \cdot 16^{*}(0 \cdot 55-46 \cdot 6)$ \\
\hline
\end{tabular}

Values are given as medians and total ranges. ${ }^{*} \mathrm{p}<0.01$ compared with the corresponding group of sham operated rats. $\dagger p<0.01$ compared with the concentration of NTLI in the ileum of resected rats.

differences found after instillation of saline, Aminess or glucose $20 \%$ were not significantly different from the controls (Table 1). The concentration of NTLI in the distal jejunum was not significantly different from the concentration of NTLI in the distal ileum (Table 2). After proximal small intestinal resection the amount of NTLI in the jejunum increased 15 times, but only by a factor 3 in the distal ileum (Table 2). Using gel chromatography, NTLI in the pooled hypertrophied jejunum and ileum specimens eluted at the same position as intact neurotensin 1-13 (Fig. 1). The number of NTLI cells per unit length of the muscularis mucosae and per 10 crypt-villi in the hypertrophied jejunum and ileum was not significantly different from controls (Table 3 ). Histologically the height of the villi and the depth of the crypts increased after proximal small intestinal resection (Fig. 2).

\section{Discussion}

In mammals NTLI is predominantly found in the jejunum and ileum, but the distribution of NTLI along the gastrointestinal tract differs among species. In man and dog the highest concentration of NTLI is found in the distal ileum. ${ }^{18}{ }^{19}$ In the rat, Carraway and Leeman ${ }^{21}$ reported nearly equal concentrations in the ileum and jejunum, while others found the highest concentration in the ileum. ${ }^{21}$ In the present study no difference was found between the concentration of NTLI in the distal jejunum and the ileum in sham operated rats. After proximal small intestinal resection the concentration of NTLI increased by a factor of 15 in the distal jejunum, but only by a factor 3 in the ileum. The increase in plasma concentration of NTLI after instillation of fat was more pronounced in resected rats than in sham operated rats. These results suggest that the adaptive changes in the distal intestine after proximal small intestinal resection may also involve the NTLI cells.

The basal plasma concentrations of NTLI were unchanged after intestinal resection. This is different from the increased concentration of enteroglucagon found in plasma after proximal intestinal resection in

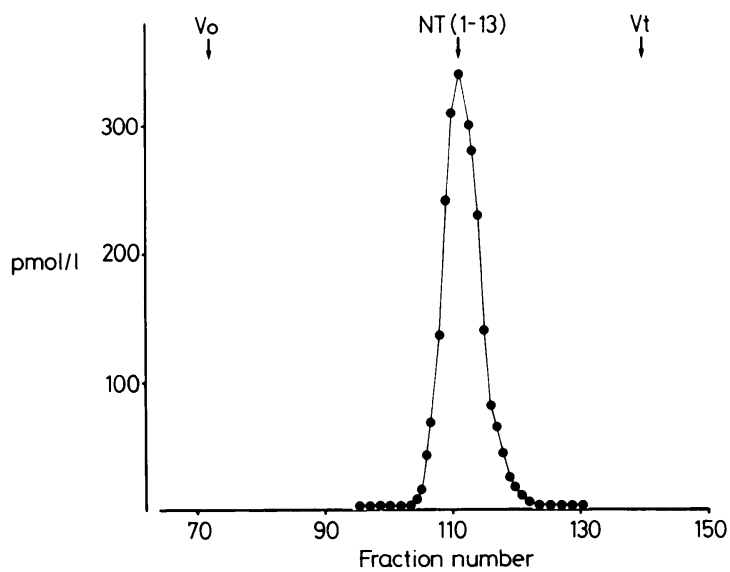

Fig. 1 Gel filtration of pooled jejunal and ileal extract from resected rats. Abscissa: Fraction number. Ordinate: Neurotensin in pmolll determined by radioimmunoassay. $V_{o}:$ Void volume, $V_{t}:$ Total volume, $N T(1-13)$ : Elution volume of synthetic NT (1-13).

the rat. ${ }^{22}$ This rise in the level of circulating enteroglucagon was not combined with increased tissue concentration of enteroglucagon in the distal small intestine. ${ }^{23}$ Immunohistochemically, a relative decrease in the enteroglucagon cell number was found. ${ }^{23}$ Ultrastructural studies showed a decrease in the number of secretory granules and more prominent Golgi complexes and endoplasmic reticulum, which suggest a hyperfunction of the enteroglucagon cells in the ileum of resected rats. ${ }^{24}$ In the resected group of rats in the present study we found an increased level of NTLI in the jejunum and ileum, no increase in the number of NTLI cells and only increased levels of circulating NTLI in response to fat. This suggests that the increased tissue concentration of NTLI accumulates in the neurotensin cell and is released only in response to a physiological stimulus - for example, fat.

After proximal small intestinal resection, the part

Table 3 Number of neurotensin immunoreactive cells per unit length of muscularis mucosae and per 10 crypt villi in the distal jejunum and ileum of sham operated rats and rats subjected to proximal intestinal resection

\begin{tabular}{llll}
\hline Organs & Operation & $\begin{array}{l}\text { Cells/ } \\
\text { unitlength }\end{array}$ & $\begin{array}{l}\text { Cells/ } \\
\text { locrypt villi }\end{array}$ \\
\hline Jejunum & Shamoperation & $4(2-6)$ & $5(4-8)$ \\
Jejunum & Resection & $4(3-7)$ & $5(2-6)$ \\
Ileum & Sham operation & $5(3-8)$ & $6(4-9)$ \\
Ileum & Resection & $4(2-5)$ & $5(3-8)$ \\
\hline
\end{tabular}

Results are given as medians and total ranges. In each group of rats 10 sections from each rat were counted. No statistical difference was found between the individual groups. 


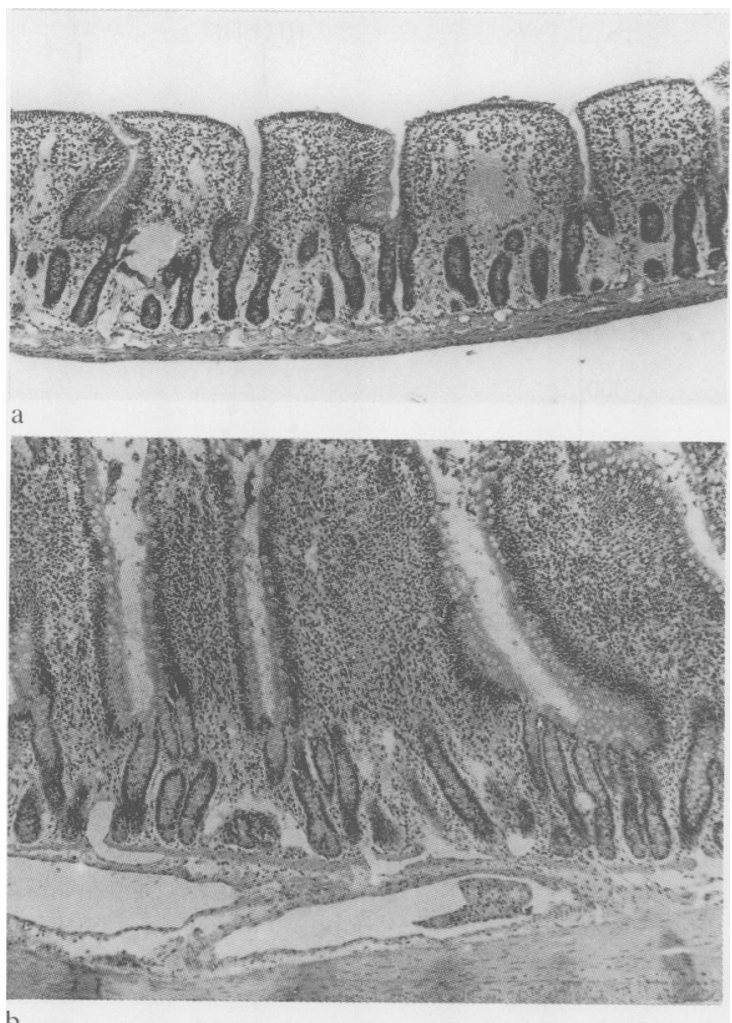

Fig. 2 (a) Transverse section of ileum from control rat. (b) Similar histologic section of ileum from resected rat. Crypt and villus height is considerably increased. Muscle layers are also thickened. (PAS-haematoxylin-Aurentia).

of the intestine richest in NTLI cells is transposed proximally and thereby exposed to a more nutrient rich chyme. This might be responsible for the increased NTLI response to fat. In addition, absorption of nutrients is further enhanced by a reduction in intestinal motility and transit time after resection, allowing prolonged contact between food and mucosa." On the other hand a large proportion of the neurotensin immunoreactive cells in the gastrointestinal tract is removed at the operation while the remaining small intestine develops increased concentrations of NTLI. The NTLI response to fat in rat and man occurs rapidly, within $10-20$ minutes, which is less than a mixed meal requires to reach the distal ileum. ${ }^{2-27}$ Experimental studies have suggested that the early release of NTLI after oral administration of fat is partly mediated by a cholinergic non-vagal mechanism. ${ }^{2 \times 29}$ These observations indicate that the increased plasma concentration of NTLI in resected rats receiving fat is a response to a larger input of nutrients to the distal small intestine.

In conclusion this study has shown, that after proximal small intestinal resection an increased concentration of NTLI is found in the remaining small intestine, and that increased concentrations of NTLI can be elicited by intragastric instillation of fat. This study suggests that NTLI may play a role in the adaptive response occurring in the small intestine after resection.

The skilful technical assistance of Henny Ploeger, Jette Schousboe, Winnie Stavnstrup and Inge Mortensen is greatly acknowledged.

\section{References}

1 Carraway $\mathrm{R}$, Leeman SE. The isolation of a new hypotensive peptide from bovine hypothalami. $J$ Biol Chem 1973; 248: 6854-1.

2 Schultzberg M, Hökfelt T, Nilsson G, et al. Distribution of peptide-and catecholamine-containing neurons in the gastrointestinal tract of rat and guinea pig: immunohistochemical studies with antisera to substance $P$, vasoactive intestinal polypeptide, enkephalins, somatostatin, gastrin/cholecystokinin, neutorensin and dopamine $\beta$-hydroxylase. Neuroscience 1980; 5: 689-744.

3 Polak JM, Sullivan SN, Bloom SR, et al. Specific localisation of neurotensin to the $N$ cell in human intestine by radioimmunoassay and immunohistochemistry. Nature 1977; 270: 183-4.

4 Reinecke M, Almasan K, Carraway R, Helmstacdter V, Forssmann WG. Distribution patterns of neurotensinlike immunoreactive cells in the gastrointestinal tract of higher vertebrates. Cell Tissue Res 1980; 205: 383-95.

5 Rosell S, Rökaeus $\AA$. Actions and possible functions of circulating neurotensin. Clin Physiol 1981; 1: 3-20.

6 Ferris CF, Hammer RA, Lceman SE. Elevation of plasma neurotensin during lipid perfusion of rat small intestine. Peptides 1981; 2: suppl 2: 263-6.

7 Gleeson $\mathrm{MH}$, Cullen J, Dowling RH. Intestinal structure and function after small bowel by-pass in the rat. Clin Sci 1972; 43: 731-42.

8 Booth CC, Evans KT, Menzies T, Street DF. Intestinal hypertrophy following partial resection of the small bowel in the rat. BrJ Surg 1959; 46: 403-10.

9 Dowling RH, Booth CC. Structural and functional changes following small intestinal resection in the rat. Clin Sci 1967; 32: 139-49.

10 Nygaard K. Resection of the small intestine in rats IV. Adaption of gastrointestinal motility. Acta Chir Scand 1967; 133: 407-16.

11 Feldman EJ, Dowling RH, McNaughton J, Peters TJ. Effects of oral versus intravenous nutrition on intestinal adaptation after small bowel resection in the dog. Gastroenterology 1976; 70: 712-9.

12 Altmann GG. Influence of bile and pancreatic secretions on the size of the intestinal villi in the rat. $\mathrm{Am}$ J Anat 1971; 132: 167-78.

13 Al-Mukhtar MYT, Sagor GR, Ghatei MA, et al. The relationship between endogenous gastrointestinal hormones and cell proliferation in models of adaptation. In: Robinson JWL, et al, eds. Mechanisms of intestinal adaptation. Lancaster: MIT Press Ltd, 1982: 243-56. 
14 Frigerio B, Ravazola M, Ito S, et al. Histochemical and ultrastructural identification of neurotensin cells in the dog ileum. Histochemistry 1977; 54: 123-31.

15 Sagor GR, Al-Mukhtar MYT, Ghatei MA, Wright NA, Bloom SR. The effect of altered luminal nutrition on cellular proliferation and plasma concentrations of enteroglucagon and gastrin after small bowel resection in the rat. Br J Surg 1982; 69: 14-18.

16 Holst Pedersen J, Fahrenkrug J. Neurotensin-like immunoreactivities in human plasma: feeding responses and metabolism. Peptides 1986; 7: 15-20.

17 Holst Pedersen J, Stadil F, Fahrenkrug J. Preparation of ${ }^{125} \mathrm{I}-(\mathrm{Tyr} 3)$ - and ${ }^{125} \mathrm{I}-(\mathrm{Tyr} 11)$-neurotensin for radioimmunoassay. Scand J Clin Lab Invest 1983; 43: 483-91.

18 Sundler F, Håkanson R, Hammer RA, et al. Immunohistochemical localization of neurotensin in endocrine cells of the gut. Cell Tiss Res 1977; 178: 313-21.

19 Doyle H, Greely GH, Laszlo M, Sakamoto T, Towmsend CM, Thompson JC. Distribution of neurotensin in the canine gastrointestinal tract. Surgery 1985; 97: 337-41.

20 Carraway R, Leeman SE. Characterization of radioimmunoassayable neurotensin in the rat. $J$ Biol Chem 1952; 251: 7045-52.

21 Iwasaki Y, Seiki I, Shibata A. Radioimmunoassay of neurotensin and the distribution and concentration of gut neurotensin in rat and dog. Tohoku J Exp Med 1980; 130: $129-37$.

22 Gòrnacz GE, Al-Mukhtar MYT, Ghatei MA, Sagor GR, Wright NA, Bloom SR. Pattern of cell proliferation and enteroglucagon response following small bowel resection in the rat. Digestion 1984; 29: 65-72.

23 Polak JM, Ferri G-L, Harris A, et al. Dynamics of the enteroglucagon cell during intestinal adaptation. In: Robinson JWL, et al, eds. Mechanisms of intestinal adaptation. Lancaster: MTP Press Ltd, 1982: 257-67.

24 Buchan AMJ, Griffiths CJ, Morris JF, Polak JM. Enteroglucagon cell hyperfunction in rat small intestine after gut resection. Gastroenterology 1985; 88: 8-12.

25 Theodorsson-Norheim E, Rosell S. The effect of duodenal administration of fatty acids, triolein, liquid paraffin and lecitin on plasma neurotensin-like immunoreactivity (p-NTLI) in the rat. Acta Physiol Scand 1983; 117: 439-43.

26 Rosell S, Rökaeus $\AA$. The effect of ingestion of aminoacids, glucose and fat on circulating neurotensin-like immunoreactivity (NTLI) in man. Acta Physiol Scand 1979; 107: 263-7.

27 Clain JE, Go VLW, Malagelada JR. Inhibitory role of the distal small intestine on the gastric response to meals in man. Gastroenterology 1978; 74: 704-7.

28 Fletcher DR, Shulkes A, Bladin PHD, Hardy KJ. The effect of atropine on bombesin and gastrin releasingpeptide stimulated gastrin, pancreatic polypeptide and neurotensin release in man. Regul Peptides 1983; 7: 31-40.

29 Fletcher DR, Shulkes A, Bladin PHD, Booth D, Hardy KJ. Cholinergic inhibition of meal stimulated plasma neurotensin-like immunoreactivity in man. Life Sci 1983; 33: 863-9. 